\title{
Genetics and Breeding for Glandless Upland Cotton With Improved Yield Potential and Disease Resistance: A Review
}

\author{
Jinfa Zhang ${ }^{1 *}$ and Tom Wedegaertner ${ }^{2}$ \\ ${ }^{1}$ Department of Plant and Environmental Sciences, New Mexico State University, Las Cruces, NM, United States, ${ }^{2}$ Cotton \\ Incorporated, Cary, NC, United States
}

\section{OPEN ACCESS}

Edited by:

Linghe Zeng,

USDA-ARS Crop Genetics Research

Unit, United States

Reviewed by:

Wayne Smith,

Texas A\&M University, United States

Devendra Pandeya,

Texas A\&M University, United States

Jack McCarty,

USDA/ARS, United States

${ }^{*}$ Correspondence:

Jinfa Zhang

jinzhang@nmsu.edu

Specialty section:

This article was submitted to

Plant Breeding,

a section of the journal

Frontiers in Plant Science

Received: 04 August 2021

Accepted: 14 September 2021

Published: 06 October 2021

Citation:

Zhang $\mathrm{J}$ and Wedegaertner $T$

(2021) Genetics and Breeding

for Glandless Upland Cotton With Improved Yield Potential and Disease

Resistance: A Review.

Front. Plant Sci. 12:753426. doi: 10.3389/fpls.2021.753426
Glandless cotton (devoid of toxic gossypol) can be grown as a triple-purpose crop for fiber, feeds, and food (as an oil and protein source). However, its sensitivity to insect pests and its low yield due to the lack of breeding activities has prevented the realization of its potential in commercial seed production and utilization. Since the mid-1990s, the commercialization of bollworm and budworm resistant Bt cotton and the eradication of boll weevils and pink bollworms have provided an opportunity to revitalize glandless cotton production in the United States. The objectives of this study were to review the current status of genetics and breeding for glandless cotton, with a focus on the progress in breeding for glandless Upland cotton in New Mexico, United States. Because there existed a 10-20\% yield gap between the best existing glandless germplasm and commercial Upland cultivars, the breeding of glandless Upland cultivars with improved yield and disease resistance was initiated the New Mexico State University more than a decade ago. As a result, three glandless Upland cultivars, i.e., long-staple Acala 1517-18 GLS, medium staple NuMex COT 15 GLS, and NuMex COT 17 GLS with Fusarium wilt race 4 resistance were released. However, to compete with the current commercial glanded cotton, more breeding efforts are urgently needed to introduce different glandless traits (natural mutations, transgenic or genome-editing) into elite cotton backgrounds with high yields and desirable fiber quality.

Keywords: cotton, glandless cotton, genetics, breeding, pest responses

\section{BACKGROUND}

Cotton (Gossypium spp.) is the most important fiber crop in the world and one of the most important oilseed crops along with soybean, rapeseed, sunflower, and peanut. ${ }^{1}$ Currently, cottonseed, traditionally treated as a by-product in cotton production, is primarily used for cooking oil and animal feed (Cherry et al., 1978, 1981; Cherry, 1983; Cherry and Leffler, 1984), and provides about $14-19 \%$ of the farm-gate value in cotton production. ${ }^{2}$ Cotton produces $150 \mathrm{~kg}$ of cottonseed for every $100 \mathrm{~kg}$ of lint fibers produced (O'Brien et al., 2005). Cottonseed oil is predominantly used in food service due to its exceptional high-temperature frying characteristics and is also used in processed foods where it contributes to extended shelf life. Unlike other plant seed oils, the toxic gossypol in cottonseeds needs to be chemically removed during seed crushing and oil refining

${ }^{1}$ www.statista.com/statistics/267271/worldwide-oilseed-production-since-2008

${ }^{2}$ www.cotton.org/econ/cropinfo/costsreturns/usa.cfm 
before it can be used for human consumption. The cottonseed crushing industry estimated this to add $20 \%$ of the cost in cottonseed processing. Glandless cotton will produce cottonseeds devoid of gossypol which will be much easier and cheaper to convert to refined edible oil. Glandless cotton will also make cottonseeds an important protein source for human consumption especially in major cotton-growing developing countries (Rathore et al., 2020).

The growth of the global human population demands an increased production of food, fiber, and feeds. However, crop production is restrained by climate conditions, including the increased drought frequency and salinity in agricultural lands. Because of the reduction in insect pressure owed to the widespread use of the insect-resistant transgenic Bt cotton, there is a recent renewed interest in the research and usage of glandless Upland cotton (G. hirsutum L.). Glandless cotton can produce glandless seeds which may be used for human food (as an oil and/or protein source) and animal feed, even though it was reported that glandless cottonseed products might cause hypersensitive allergic reactions in a very small percentage of humans (Atkins et al., 1988). Potentially, the commercial production and processing of glandless cottonseeds can significantly increase the net income for both cotton producers and processors, making cotton a triple-purpose (fiber, feed, and food) crop.

The objectives of this study were to review the current status of genetics and breeding for glandless cotton, with a focus on the progress in breeding for glandless Upland cotton in New Mexico, United States (Zhang et al., 2014a,b,c,d, 2016a, 2017, 2018, 2019b,c; Zhang et al., 2020b). Other relevant studies on glandless cotton from New Mexico, such as responses to insects and crop management practices, were also mentioned in this study. A review of the processing and utilization of glandless cottonseed can be found in the study by Lusas and Jividen (1987). Recently, Rathore et al. (2020) published a comprehensive review on glandless cotton research including the biosynthetic pathway of gossypol and related terpenoids, animal feeding studies, and human nutrition studies.

\section{SOURCES AND GENETICS OF THE GLANDLESS TRAIT}

There are four genetic sources for the potential glandless cottonseed production. The first natural glandless mutant (with no gland on the plant and seed) in Upland cotton was discovered by McMichael (1959), which is conditioned by two recessive alleles, namely, $g l_{2}$ and $g l_{3}$ (McMichael, 1960). The two glandless genes, $g l_{2}$ and $g l_{3}$, did not exhibit any deleterious effects on the lint yield and fiber quality, however, contributed to the lower cottonseed yield, smaller seed size, and higher lint percentage in glandless cotton (Halloin et al., 1978). The two genes were later mapped to chromosomes ( $G l_{2}$ to A12 and $G l_{3}$ to D12) through linkage analysis (Lee, 1965; Endrizi et al., 1985; Kohel, 1979) and molecular mapping (Dong et al., 2007). While normal glanded cotton carries homozygous dominant $\mathrm{Gl}_{2} \mathrm{Gl}_{2} \mathrm{Gl}_{3} \mathrm{Gl}_{3}$ (provides ca. $1 \%$ of the gossypol content in seeds and plants), the distribution of glands or gossypol content may be changed by the other alleles of the two genes and other glanded loci $\left(G l_{1}, G l_{4}, G l_{5}\right.$, and $\left.G l_{6}\right)$ with different alleles from different genetic sources (Wilson and Smith, 1977; Lee, 1978; Endrizi et al., 1985; Calhoun, 1997).

The second glandless cottonseed source was an induced dominant glandless mutation, identified in "Bahtim 110," which was derived from the irradiation of seeds from the Egyptian cotton (G. barbadense L.), "Giza 45" (Afifi et al., 1966). The glandless (with no glands in the plants and seeds) trait is conditioned by a dominant gene, $G l_{2}{ }^{e}$, which is allelic to $g l_{2}$, although marginal or reduced glandedness in the cotyledons and hypocotyls were also observed in heterozygotes (Kohel and Lee, 1984). $G l_{2}{ }^{e}$ is epistatic to $G l_{3}$ in that it suppresses the expression of the glanded $\mathrm{Gl}_{3}$ gene that renders glandless plants and seeds in the $\mathrm{Gl}_{2}{ }^{e} \mathrm{Gl}_{2}{ }^{e} \mathrm{Gl}_{3} \mathrm{Gl}_{3}$ genotype. The genetic basis was later confirmed in other genetic backgrounds or advanced backcrosses (De Carvalho and De Macedo Vieira, 2000; Hinze and Kohel, 2006). For example, when this gene was incorporated in the commercial Brazilian Upland cultivar CNPA Precoce 2, a few glands were shown in the cotyledons of the heterozygous plants, indicating the incomplete dominance of the glandless trait, but the $\mathrm{F}_{1}$ seed had gossypol-free content, similar to the homozygous $\mathrm{Gl}_{2}{ }^{e} \mathrm{Gl}_{2}{ }^{e}$ parent (De Carvalho and De Macedo Vieira, 2000). The $\mathrm{Gl}_{2}{ }^{e}$ gene was fine mapped within a $15 \mathrm{~kb}$ region in chromosome A12 with only one gene (with $1428 \mathrm{bp}$ ) encoding for a basic helix-loop-helix (bHLH) transcription factor of 476-amino acids (Cheng et al., 2016; Ma et al., 2016), which was named as the Gossypium pigment gland formation gene (GoPGF) by Ma et al. (2016). Through homologous gene cloning and sequencing, Ma et al. (2016) further showed that the single " $T$ " nucleotide insertion between 735 and $736 \mathrm{bp}$ in the coding region of GhPGF_A12 ${ }^{m}$ is the likely causal gene for the recessive glandless $g l_{2}$ allele in A12, while the single " $\mathrm{A}$ " nucleotide insertion between 916 and 917 bp in the coding region of GhPGF_D12 ${ }^{m}$ is likely the causal gene for the recessive glandless $g l_{3}$ allele in D12. The two single nucleotide insertions caused the premature translation termination of the encoded transcription factors, making the truncated proteins non-functional.

The third source, a glanded plant and glandless cottonseed trait with delayed pigment gland morphogenesis, was found in a few wild diploid Australian cotton species, as represented by G. bickii. Attempts have been made for the interspecific crossing between these Australian species and Upland cottons, such as through a tri-specific hybridization between amphidiploid $\left[(G\right.$. arboreum $\times G$. bickii $) \mathrm{F}_{1}\left(2 \mathrm{n}=52, \mathrm{~A}_{2} \mathrm{~A}_{2} \mathrm{G}_{1} \mathrm{G}_{1}\right)$, (G. herbaceum $\times$ G. astrale) $\mathrm{F}_{1}\left(2 \mathrm{n}=52, \mathrm{~A}_{1} \mathrm{~A}_{1} \mathrm{G}_{2} \mathrm{G}_{2}\right)$, or (G. thurberi $\times$ G. sturtianum $\left.) \mathrm{F}_{1}\left(2 \mathrm{n}=52, \mathrm{D}_{1} \mathrm{D}_{1} \mathrm{C}_{1} \mathrm{C}_{1}\right)\right]$ and G. hirsutum (Bi et al., 1999; Zhu et al., 2004, 2005; Liu et al., 2015). There have also been attempts through synthetic hexaploid avenues such as between the G. hirsutum-G. bickii amphidiploid $\left(2 \mathrm{n}=78, \mathrm{AADDG}_{1} \mathrm{G}_{1}\right)$ and $G$. hirsutum (Tang et al., 2018), or between the G. hirsutum-G. raimondii amphidiploid $(2 \mathrm{n}=78$, $\mathrm{AADDD}_{5} \mathrm{D}_{5}$ ) and G. sturtianum (Bi et al., 1999). However, the trait has not been successfully transferred into Upland cotton for utilization in research due to the difficulty in interspecific introgression. Therefore, the genetic basis (such as the number of genes, gene effects, and chromosomal locations) for the 
characteristic- glanded plant and glandless cottonseed trait with delayed pigment gland morphogenesis is still unknown.

The fourth source, a genetically engineered (GE) Upland cotton, producing ultra-low gossypol cottonseeds (ULGCS), was produced by Sunilkumar et al. (2006), based on RNA interface (RNAi) to silence the delta-cadinene synthase gene(s) driven by a seed-specific $\alpha$-globulin promoter. The ULGCS and glanded plant trait were reported to be stable under both greenhouse and field conditions (Rathore et al., 2012; Palle et al., 2013). As compared with the Coker 312 used for the transformation, the three ULGCS lines tested appeared to have similar leaf terpenoid and gossypol content, lint yield, seed protein content, and fiber quality, but 4-8\% higher seed oil content (Rathore et al., 2012; Palle et al., 2013). As compared with the normal glanded Coker 312, the developing cotyledons of the transformed ULCGS cotton appeared to have a lower level of gossypol content, incurring a higher level of damage from African cotton leafworms, Spodoptera littoralis (Boisd.), while the fully expanded true leaves showed similar responses to the insect (Hagenbucher et al., 2019). Rathore et al. (2020) have recently provided a detailed account of events that led to the development of ULCGS. The petition for the deregulation of the GE low-gossypol trait was recently approved by both the United States Department of Agriculture (USDA) (in Oct. 2018) and the Food and Drug Administration (FDA) (in Sept. 2019) (Rathore et al., 2020). The introduction of this trait to elite cotton has been ongoing but has made slow progress due to the concerns about international regulatory hurdles. There were other attempts in developing transgenic or non-transgenic glandless cotton. For example, most recently, Li et al. (2021) reported using the temperature-sensitive CRISPR/LbCpf1 (LbCas12a) mediated-genome editing system to successfully create non-transgenic gossypol-free Upland cotton. Other genes (Tian et al., 2018; Janga et al., 2019; Gao et al., 2020), involved in gland formation and the gossypol biosynthetic pathway, can be targets for genetic modification to produce glandless cottonseed.

\section{BREEDING FOR GLANDLESS UPLAND COTTON}

Since the discovery of the double recessive glandless $\left(g l_{2} g l_{2} g l_{3} g l_{3}\right)$ cotton by McMichael (1959, 1960), numerous efforts have been made in breeding and researching glandless cotton in the United States until the 1970s, which were summarized in a conference entitled "Glandless cotton-its significance, status and prospects" published in 1978 (Anonymous, 1978). Numerous improved glandless germplasm lines were developed and released. Thaxton et al. (1987) reported progress in developing glandless cotton in the multi-adversity resistant (MAR) program and showed that the new glandless GCANH-1-83 MAR strain had improved yield potential, fiber quality, and disease resistance that was equal to the latest releases of Tamcot cultivars such as the CAMD-E but was slightly less resistant to insects (Thaxton et al., 1998). Seed companies and public breeders developed several commercial glandless cultivars; however, glandless cotton was grown in only a very limited acreage in central Texas and the
Texas High Plains in the mid-1980s. However, dehulled, roasted, and whole glandless kernel products and associated business did not gain much of the market, due to quality control, insects, and marketing issues, in addition to possible allergenic reactions (Hinze and Kohel, 2012). Since then, there were intermittent breeding activities until the late 1990s (Shepherd, 1982; Smith and Niles, 1988; Owen and Gannaway, 1995; Dobbs and Oakley, 2000). Using the glandless trait as a genetic marker, breeding populations using Upland cotton lines with varying gland densities involving glandless cotton were recently developed (Gutiérrez et al., 2006; Scheffler and Romano, 2012; Hinze et al., 2014). The potential of glandless cottonseeds in cotton production and product development as a triple-purpose crop (fiber, feeds, and food) has not been realized in the United States.

In the 1970s, glandless germplasm (with the $g l_{2} g l_{2} g l_{3} g l_{3}$ genotype) was introduced from the US to other cotton-growing areas including Africa and China, and the breeding for glandless Upland cotton was subsequently conducted. Hau (1987) reported that 24,000 hectares were cultivated in Ivory Coast in 1984 with the glandless variety, ISA BC2, created by IRCT-IDESSA in Bouak. China released at least 20 glandless Upland cotton cultivars (Ma et al., 2016).

Although the genetic study on $\mathrm{Gl}_{2}{ }^{e}$ was conducted in the US (Kohel and Lee, 1984), no breeding activities were recorded using this glandless source. The National Cotton Germplasm Collection does not have accessions possessing the $G_{2}{ }^{e}$ gene, and the glandless accessions are all homozygous recessive $g l_{2} g l_{2} g l_{3} g l_{3}$. However, the dominant glandless $\mathrm{Gl}_{2}{ }^{e}$ gene was introduced from $G$. barbadense into Upland cotton through interspecific hybridizations and backcrossings in China (Yuan et al., 2000). Based on a field study on seven pairs of near-isogenic lines (NILs) with glanded or dominant glandless traits in Upland cotton, Yuan et al. (2000) did not detect significant associations between the dominant glandless gene and most agronomic, fiber, and seed quality traits; however, the oil or protein content was higher in one glandless line than in its glanded NIL. Advanced backcross populations involving the $\mathrm{Gl}_{2}{ }^{e}$ gene were used in a quantitative trait locus (QTL) mapping for yield, yield component traits, fiber quality, and disease resistance by the Yuan group (Shi et al., 2016, 2019; Li et al., 2019). A new Upland cotton cultivar with glanded plants and seeds with low gossypol content was reportedly released (Zhang et al., 2001); however, its authenticity was not independently verified.

\section{RESPONSES TO INSECT PESTS IN GLANDLESS COTTON}

Glands containing toxic gossypol and other terpenoid aldehydes are distributed in most of the tissues and organs of cotton, which plays an important role in defending cotton against insect pests that feed on its tissues and organs. Glandless cotton eliminates this protection and incurs heavier insect damage than conventional glanded cotton (Benedict et al., 1977). In addition, glandless cotton is susceptible to field mice and foraging by livestock and wildlife animals. This has become one of the most important limiting factors preventing the commercial production 
of glandless cotton. Therefore, a more detailed review of the responses of glandless cotton to insect pests is warranted here.

\section{Boll Weevils (Anthonomus grandis Boheman)}

The boll weevil had been a major cotton insect in the US Cotton Belt until its successful eradication in the early 2000s. Stephens and Lee (1961) compared the feeding and oviposition preferences of boll weevils among a standard Upland cotton cultivar and three mutant strains, namely, hairy, hairy-glandless, and hairy-glandless-red, in laboratory tests and a field test, and no discriminations were observed between glandless and glanded cotton. Through a 2-year field study to compare two pairs of glanded and glandless NILs in large plots and 13 pairs of glanded and glandless NILs in small plots in Mississippi, Jenkins et al. (1967) showed that glandless cotton possessing the two glandless genes, $g l_{2}$ and $g l_{3}$, were not more susceptible, although the boll weevils were slightly larger on some glandless NILs. In another companion laboratory study, Maxwell et al. (1966) showed that the weevils fed significantly less on six glandless lines than on their glanded parental NILs and laid significantly more eggs on three glandless lines than on their glanded NILs, while there was no difference detected in the oviposition rate between the nine pairs of glandless and glanded NILs. The weevils reared on square powder diets made from three glandless lines were larger than those with similar diets made from their glanded NILs, while the opposite was true for the other paired lines. No significant difference was observed in the developmental period of weevils between the glandless and glanded paired NILs studied. The results from both studies led to the conclusion that the double recessive glandless trait will not increase boll weevil susceptibility in some genetic backgrounds. In a 4-year field study at Stoneville, Mississippi, Merkl and Meyer (1963) showed that the level of the punctured squares by weevils on the glandless cotton was the same as the cotton lines with smooth leaves or the nectariless trait, and factors such as plant height, leaf color, and growth characteristics affected the percentage of the infested squares. Through an inheritance study in the $\mathrm{F}_{1}, \mathrm{~F}_{2}$, and backcross progeny of the cross with Upland Deltapine Smooth Leaf (DPSL), Buford et al. (1968) showed that among the 252 cotton lines tested, "S. I. Seaberry" (G. barbadense) produced the lowest oviposition rate by the weevils, and possessed a genetic factor (X factor) that suppresses weevil oviposition. However, the gossypol content in cotton is related to the preference of weevils in feeding and oviposition. When the gossypol contents increased to levels higher than normal in cotton, the weevils preferred feeding and oviposition on glandless (with no gossypol) or normal-glanded (normal gossypol content) strains (Singh and Weaver, 1972).

\section{Helicoverpa spp.}

Glandless cotton is highly susceptible to Helicoverpa (often called heliothis), including tobacco budworm $[H$. virescens $(\mathrm{F})$.$] , corn$ earworm [H. zea (Boddie)] and bollworm (H. armigera Hubner), a serious pest in cotton in most cotton-growing countries. It appears that Helicoverpa cannot metabolize the gossypol but excretes it to a certain degree (Montandon et al., 1987). The first stage larvae of $H$. spp. were shown to avoid feeding on the gossypol glands of anthers or other parts of the cotton plant due to the presence of allelochemicals including anthocyanins, but then non-selectively consumed the glands (Belcher et al., 1983; Parrott et al., 1983; Parrott, 1990), and they were, therefore, feeding less frequently and resting more on the glanded cotton than on glandless cotton (Schmidt et al., 1988). Consequently, the H. zea or H. virescens larvae feeding on glandless cotton grew faster and gained more weight (Lukefahr et al., 1966; Meredith et al., 1979; Montandon et al., 1986, 1987; Scheffler et al., 2012), had increased survival rates and shorter developmental time, and caused more damage on the cotton (Mullins and Pieters, 1982; Zummo et al., 1983; Wang et al., 2008; Pierce et al., 2012, 2014; Garnett et al., 2013). The number of dominant glanded alleles is associated with the preference of $H$. virescens in that the larvae favored glandless $\left(g l_{2} g l_{2} g l_{3} g l_{3}\right)$ seedlings, and the preference was decreased as the number of $\mathrm{Gl}_{2}$ and $\mathrm{Gl}_{3}{ }^{\text {ral }}$ alleles increased (Wilson and Lee, 1971). Wilson and Lee (1971) indicated that the number of pigment glands on the cotyledonary petiole and percentage of seed gossypol were correlated with seedling damage and the number of larvae that $H$. virescens left on the seedlings. Glandless cotton not only lacks gossypol but also lacks or contains small quantities of volatile terpenes (Elzen et al., 1985). Lukefahr and Houghtaling (1969) found that cotton with high gossypol (HG) contents (1.7\%) inhibited the growth of $H$. spp. Shaver et al. (1980) observed a significant linear relationship between the reduction in larval weight of tobacco budworms and gossypol content in squares. Commercial Upland cotton normally exhibits an approximate $3(+)$-gossypol to $2(-)$-gossypol ratio and Stipanovic et al. (2006) showed that both $(+)$-gossypol and (-)-gossypol were equally inhibitory to $H$. zea larvae, although (+)-gossypol is less toxic than (-)-gossypol to non-ruminant animals. In a feeding study to compare three pairs of glanded and glandless NILs using leaves and artificial diets with five levels of gossypol content, Kong et al. (2010) found that the glanded cotton and diets with higher levels of gossypol decreased larval weights and moth eclosion rates and delayed the development of the larvae and pupae of H. armigera; and the larvae that fed on the glanded cotton leaves were more tolerant to two insecticides (cyhalothrin and monocrotophos). In studies comparing 14 pairs of normally glandless and glanded cotton NILs, the increased larval growth of $H$. zea was only observed when they fed on diets of glandless cotton (Lukefahr et al., 1966; Oliver et al., 1971), but there were no significant differences between any glandless vs. glanded pairs in the number of eggs oviposited or in the number of squares and bolls damaged by the H. zea in field plots (Oliver et al., 1970a,b). Additionally, in field studies, Jenkins et al. (1966) showed that $H$. zea caused similar damages on the Rex Smooth leaf glanded and glandless cotton lines and glanded Deltapine Smooth Leaf, but the glandless Acala incurred higher damage than glanded Acala cotton.

The resistance of glandless cotton to the damages from $H$. spp. can be improved to the level of glanded cotton by using Bt genes. Benedict et al. (1993) showed that two glandless lines with Bt genes reduced the larval survival of $H$. zea to nearly zero with no damage to the squares and bolls, as compared to the average 
of $24-33 \%$ survival rates on glanded non-Bt NILs. However, it appeared that no commercial cotton cultivars possessing both glandless and Bt traits were developed and commercialized.

\section{Armyworm (Spodoptera spp.)}

In field conditions, Bottger et al. (1964) observed that beet armyworms [S. exigua (Hübner)] preferred glandless cotton over glanded cotton. In laboratory bioassays, McAuslane and Alborn (1998) confirmed that S. exigua larvae strongly preferred feeding on glandless cotton when given a choice between glanded and glandless cotton plants. In a greenhouse study, McAuslane and Alborn (2000) further showed that neonate beet armyworms avoided feeding on the gossypol-rich young leaves of glanded cotton plants because they moved down the plant to feed on the older leaves when placed on the terminal foliage; however, the larvae feeding on glandless plants were evenly distributed within the plant. In a no-choice laboratory study, even though the larvae feeding on young or mature leaves from the glanded or glandless plants had similar survival rates, the pupae and adults from the larvae reared on the young or old leaves of glanded cotton weighed significantly less than those on the glandless plants. In addition, the time to pupation and adult emergence was significantly longer for the larvae fed on glanded plants. In New Mexico, Pierce et al. $(2012,2014)$ and Garnett et al. (2013) reported that beet armyworms caused higher leaf damage and took a shorter time to pupation with 2-6 times higher survival rates when fed on glandless Acala GLS as compared to glanded Acala 1517-99. In Israel, Meisner et al. (1977c) compared the effects of different cotton strains with different gossypol contents of leaves on the development of $S$. littoralis larvae and showed that the larvae fed on HG (1.23\%) strain had lower weight, required longer time for pupation, and reduced pupal weight and pupation rate. The S. littoralis larvae fed on only half of the food containing an extract from the HG cotton strain than that containing an extract of a glandless strain (Meisner et al., 1977a). Zur et al. (1978) determined the gossypol content of the cotyledons and true leaves during the growing season in $12 \mathrm{HG}$ Upland cotton lines, a normal glanded cultivar, and a glandless line, and the $S$. littoralis larvae feeding on the glandless cotyledons gained the highest weight and the lowest on the three HG lines. Zur et al. (1980) further confirmed the value of HG cotton strains in suppressing S. littoralis and Earias insulana (Boisd.) populations as compared with a glandless strain and a normal glanded Upland cultivar, in unsprayed fields of two production regions. Similar to S. exigua, an avoidance strategy was reported for the S. littoralis larvae that avoided gossypol-rich young leaves by migrating from the young leaves to the older leaves (Anderson et al., 2001). Meisner et al. (1977b) showed that glandless cotton reduced the effectiveness of phosfolan (2-(diethoxyphosphinylimino)-1,3dithiolane in controlling S. littoralis.

\section{Plant Bugs (Lygus spp.)}

Plant bugs are a serious mid-season insect pest problem in cotton production, as they prefer to feed on the squares and young bolls. The western tarnished plant bug (WTPB) (L. hesperus Knight) feeding on glandless cotton increased its growth rate and survival of nymphs by twofold, resulting in a 2.5 times greater WTPB population and a $57 \%$ reduction in cotton bolls in California (Tingey et al., 1975; Benedict et al., 1981; Leigh et al., 1985). However, the susceptibility of glandless cotton is dependent on genetic backgrounds. In a field cage study, Leigh et al. (1985) showed that 32 glandless lines supported 1.9- to 2.5-fold higher WTPB than the glanded "Acala SJ-2," whereas 20 other glandless lines did not differ from Acala SJ-2 in WTPB populations. Thirty-seven glandless lines were selected to further evaluate the effect of cotton genotypes on nymphal survival, growth rate, and adult oviposition preference in a greenhouse. The results indicated that glandless cotton that is no more susceptible to WTPB than the glanded cultivar, Acala SJ-2, could be developed, indicating that other genetic factors can reduce the susceptibility of glandless cotton. Based on a 2-year multi-location study in the San Joaquin Valley (SJV), California, Goodell et al. (2001) found little difference among the Acala, Upland, and Pima cultivars for arthropod affinity; however, the glandless Acala cultivar C-166 had a significantly higher total population of WTPB than the other glanded cultivars in three locations over the 2 years. In Mississippi, Meredith et al. (1979) showed that glandless cotton had a higher yield loss upon infestation from tarnished plant bugs (TPB) [L. lineolaris (Palisot de Beauvois)] than without TPB; and among 99 glandless lines, the least sensitive glandless lines possessed combinations of nectarilessness, hirsuteness, or rapid fruiting ability, characteristics which were previously found to be less susceptible to TPB.

\section{Thrips (Frankliniella spp. and Thrips tabaci Lind.)}

Thrips are important insect pests at the seedling stage. Based on a leaf area reduction to measure the resistance of thrips (Rummel and Quisenberry, 1979), Quisenberry and Rummel (1979) showed that morphological traits such as glandlessness $\left(g l_{2} g l_{3}\right)$ did not provide the plant with resistance to thrips, except for Pilose $\left(\mathrm{H}_{2}\right)$ which was highly resistant. In China, glandless cotton was also more susceptible to thrips (Fang et al., 1995). Based on a field study of 11 glanded Pakistan Upland cotton and a glandless check (Rizwan et al., 2021), the glandless check had significantly higher populations of whiteflies [Bemisia tabaci (Genn.)], thrips, and jassids (Amrasca devastans Dist.), and the leaf gland density was significantly and negatively correlated with the populations of the three insect pests. However, in an extensive field study in New Mexico (Zhang et al., 2014b,d), many glandless cotton lines were compared with the glanded control Acala 1517-08 and other glanded lines for their resistance to the Western flower thrips [F. occidentalis (Pergande)]. These lines were divided into four replicated field tests, each with 32 genotypes. In the same field, many glanded commercial cultivars and breeding lines were divided into three other tests to compare with the glanded Acala 1517-08 and Acala 1517-99. Overall, the glandless cotton had similar or lower damages from thrips than the glanded cotton, indicating that the glandless trait may serve as a genetic factor for suppressing damage from thrips. As compared with Acala 1517-08 which represented one of the most thrips resistant genotypes among the glanded cotton tested, glandless 
Acala GLS and many glandless selections were more resistant, indicating that unknown genetic factors other than the glandless trait also affect thrips resistance in cotton (Zhang et al., 2014b). The results were corroborated by the development of many thrips resistant lines in an Acala 1517-08 $\times$ Acala GLS cross. Similar results were obtained in a greenhouse study (Larson et al., 2015; Larson, 2019).

\section{Other Insects}

Many secondary insects or insects that did not use normal glanded cotton as a major host were found to infest glandless cotton and cause significant damages. In Arizona, Bottger et al. (1964) observed that, in addition to H. zea and S. exigua, black fleahoppers [Spanogonicus albofasciatus (Reuter)], grape colaspis beetles [Maecolaspis flarida (Say)], cutworms (undetermined species), pill bugs (Porcellio spp.), and rodents also preferred eating glandless cotton before attacking glanded cotton under field conditions. Maxwell et al. (1965) observed greater susceptibility in several glandless experimental lines than in their glanded NILs to cotton leafworms [Alabama argillacea (Hüibner)], bollworms, grape colaspis beetles, and Gastrophysa cyanea (Melch) in Mississippi; and Japanese beetles (Popilla japonica Newman) damaged the leaves of glandless lines extensively in North Carolina. Also in Mississippi, Jenkins et al. (1966) observed a preference in feeding and oviposition on all glandless lines from adult insects such as M. flavida, G. cyanea, and $A$. argillacea that usually did not cause damage to glanded cotton, causing considerable damage to all glandless lines. Glandless cotton was also more sensitive to two-spotted spider mites [Tetranychus urticae (Koch)] (Schuster et al., 1972; Bailey and Meredith, 1983). After the glandless cotton germplasm was introduced and tested in other countries or regions such as China, India, Pakistan, Brazil, and Africa, higher insect pest pressures were also found on glandless cotton than on glanded cotton. For example, glandless cotton lines were heavily infested by sucking pests throughout the growing season in India, including cotton leafhoppers (Amrasca biguttula biguttula Ishida), jassids, B. tabaci, and T. tabaci (Bhatnagar and Sharma, 1991).

\section{Predators}

Benedict et al. (1977) reported that more predators were collected in glandless plots compared to glanded plots in California. In New Mexico, Ellington et al. (1984) showed that glandless cotton supported larger phytophagous populations than glanded cotton, but the HG genotypes did not affect the phytophagous populations and its effect on the population of predators was ambiguous. Also in New Mexico, Pierce et al. (2015, 2016, 2017) showed overall similarity in predation rates between glanded and glandless cotton based on multi-year field studies. In Brazil, Silva et al. (2002) did not observe any difference in the population density of predators between glandless and glanded genotypes.

\section{Controversial Results}

Montandon et al. (1986) fed glanded and glandless cotyledons to $A$. argillacea, a specialist on Gossypieae, and showed that the $A$. argillacea survived equally well on either cotton type but had significantly higher larval weights by feeding on the glanded leaves. The results suggested that glanded cotton may not lessen but even increase the impact of the adapted specialists on cotton. It was reported in China that glandless cultivars were more resistant to aphids (Aphis gossypii Glover) and spider mites damage than glanded ones (Fang et al., 1995). In Arizona, a glandless Pima mutant (G. barbadense) was found to suffer significantly less seed damage from pink bollworms [Pectinophora gossypiella (Saund.)] than the glanded check Pima S-4 or S-5 (Wilson et al., 1977, 1979). In Pakistan, among the 20 cotton genotypes evaluated for their resistance or tolerance to A. devastans, Scirtothrips dorsalis (Hood), T. tabaci, B. tabaci, E. insulana (Boisd.), E. vittella (F.), and pink bollworms (Baloch et al., 1982), the glandless, nectariless and gossypolfree genotypes were susceptible to the attacks by A. devastans, while the glandless, nectariless, glabrous, hairy and okra-leaf genotypes were more susceptible than the others to E. spp. and pink bollworms. In Brazil, no differences were observed between the glandless and glanded genotype population density for cotton aphids, T. tabaci, cotton leaf worms, and pink bollworms (Silva et al., 2002). It should be noted that because most of these studies with controversial results came from germplasm lines with different morphological traits, different genetic backgrounds, experimental designs, growing stages, and environmental conditions may affect the effect of glandless cotton on the growth and development of different insect pests. Because genotype $\times$ trait interactions often exist, NILs in different genetic backgrounds should be developed and used to compare glandless and glanded cotton.

McCarty et al. (1983) studied Upland cotton lines with different morphological traits in multiple locations without early season insect control, and the results showed that the nectariless lines had high adaptability, while the lines with other morphological traits, including glandlessness, did not, due likely to the varying insect pressures in different locations. In New Mexico and the other areas of the US Cotton Belt such as Arizona and Far-west Texas, the overall insect pest pressure has been low, due to the successful eradication of boll weevils and pink bollworms and the reduced damage of budworms/bollworms by growing transgenic Bt cotton. Thus, glandless cotton may not suffer from heavy insect damages and high yield losses as before. The responses of glandless cotton to phytophagous populations and predators should be studied under the current production conditions.

\section{RESPONSES TO DISEASE INFECTIONS IN GLANDLESS COTTON}

It is well known that gossypol and other related terpenoid aldehydes (TA) are phytoalexins (Rathore et al., 2020). Studies have shown that gossypol and other TA were induced in the roots or leaves of glanded cotton upon being infected by different pathogens such as soil-borne fungi (Verticillium dahliae Kleb.) causing Verticillium wilt. Fusarium oxysporum $\mathrm{f}$. sp. vasinfectum (G.F. Atkinson) Snyder \& H.N. Hansen (FOV) causing Fusarium wilt, and Xanthomonas citri pv. malvacearum causing bacterial blight; and high or elevated TA contents may 
be related to the resistance to these diseases (for a review, refer to Rathore et al., 2020). However, it is known that most glanded cotton lines are susceptible to these pathogens, while there are resistant glandless cotton genotypes. Khoshkhoo et al. (1994) compared the concentrations of TA, including gossypol, in the roots and leaves between several susceptible and resistant glanded and glandless cotton lines to root-knot nematodes (RKN) [Meloidogyne incognita (Kofoild and White) Chitwood]. They found that the TA content and its increase in the root were not associated with RKN resistance. It is now understood that the two glanded genes (on A12 and D12) and the two major resistance genes/QTLs (one on A11 and another on D02) for RKN resistance are not linked. Similarly, there is no direct linkage between glanded genes and QTLs when it comes to the resistance to bacterial blights (Zhang et al., 2020a), Verticillium wilt, and Fusarium wilt (Abdelraheem et al., 2017). In several fields and greenhouse studies, we have also found that glandless cotton was not more susceptible to Verticillium wilt than glanded cotton (Larson et al., 2015; Larson, 2019). Several new glandless cotton lines were shown to be more resistant to leaf spots [Alternaria alternata (Fr.) Keissl.] in several field tests (Zhu et al., 2017, 2018). In addition, two new glandless Upland cultivars, namely, NuMex COT 15 GLS and NuMex COT 17 GLS, were found to be as resistant to Fusarium wilt caused by Fusarium oxysporum f. sp. vasinfectum (G.F. Atkinson) Snyder \& H.N. Hansen (FOV) race 4 as the resistant glanded Pima cotton PHY 802 RF and PHY 811 RF (Zhang et al., 2020b). However, we are presently unsure if the resistance is related to a gene closely linked to the dominant glandless gene $\left(G_{2}{ }^{e}\right)$, chromosome A12, or derived from their FOV race 7-resistant Chinese Upland parent. Overall, there is no direct genetic relationship between glanded or glandless genes and the resistance to diseases or tolerance to abiotic stresses in cotton. However, under natural infections in the field, glandless cotton appeared to be more susceptible to Southwestern cotton rust (Puccinia cacabata Arth. and Holw.) than glanded cotton (Zhang et al., 2017).

\section{RESPONSES TO HERBICIDES IN GLANDLESS COTTON}

Foster et al. (1994) compared the prometryn tolerance between glanded and glandless isolines in a growth chamber and the field and showed that glandless $\left(g 1_{2} g l_{3}\right)$ cotton incurred higher photosynthetic inhibition and longer durations of inhibition by the herbicide, with $20-56 \%$ higher visual leaf injury ratings and $44-66 \%$ lower yield than the corresponding glanded isoline. The results demonstrated that lysigeneous glands enhance prometryn tolerance in cotton. Furthermore, the $G 1_{2} G 1_{2} g 1_{3} g 1_{3}$ had lesser leaf injury than the $g 1_{2} g 1_{2} G 1_{3} G 1_{3}$ isoline, indicating that the prometryn tolerance of $\mathrm{Gl}_{2}$ is higher than $\mathrm{Gl}_{3}$. Zhang et al. (2019b) conducted a field study with four replicated tests to evaluate 81 cotton genotypes, including 8 Pima and 73 Upland genotypes, and their responses to halosulfuron (Sandea) at the 45 th true-leaf stage. Three glandless cotton lines were significantly more sensitive than all the glanded cotton tested except for one sensitive glanded cultivar. However, in another study (Zhang et al., 2021), results indicated that glandless cotton was not more sensitive to trifloxysulfuron (Envoke) than glanded cotton when treated at the 7-true leaf stage.

\section{BREEDING FOR COMMERCIAL GLANDLESS COTTON CULTIVARS IN NEW MEXICO}

\section{The Yield Gap Between Glandless Cotton and Commercial Upland Cultivars}

To understand the breeding progress in long-staple Acala cotton, Acala germplasm and the cultivars released in New Mexico and California since the 1930s were collected from the National Cotton Germplasm Collection and were evaluated in the early 2000s in a field in New Mexico (Zhang et al., 2019a). The yield of the glandless Acala was much lower than that of the glanded cultivars including the control Acala 1517-99 (Cantrell et al., 2000). We subsequently initiated breeding activities to develop glandless Acala cotton with improved lint yield and fiber quality. Zhang et al. (2014e) further stated the following: "in 2010, an Acala glandless cotton (Acala GLS) released in California in 1999 (Dobbs and Oakley, 2000) was introduced and tested together with Acala 1517-99 and Acala 1517-08 (Zhang et al., 2011) in a national cotton variety test in Las Cruces, NM." To further enrich the glandless germplasm collection and evaluate their yield potential, obsolete and exotic glandless germplasm were collected and observed in a field in 2011-2012. Because of the noticeable phenotypic variation including segregation in the glandless trait, single plants were selected for seed increase and progeny tests. Existing glandless cotton germplasm was evaluated in eight replicated tests in Las Cruces, NM, the United States in 20102013, for lint yield, fiber quality, and their adaptability to the New Mexico cotton production conditions where Acala cotton has been traditionally grown. Zhang et al. $(2014 a, c)$ showed that the glandless Acala GLS produced only $65-80 \%$ lint yield of Acala 1517-08 and 46-75\% lint yield of transgenic cultivars in multiple tests. Idowu et al. $(2011,2012,2013 a, 2014)$ also showed that Acala GLS produced 50\% less lint than the glanded Acala 151799 in New Mexico. Even though the two other glandless cotton lines (JACO developed in Louisiana and STV GL developed in Mississippi) yielded $12-21 \%$ more than Acala GLS, they only yielded $57-63 \%$ of Acala $1517-08$ and $51-55 \%$ of the commercial transgenic PHY 375 WRF. In another replicated test in 2012, 14 obsolete US glandless lines were tested and most of them yielded below $80 \%$ of the lint of Acala 1517-08.

\section{Selection Within Existing Glandless Germplasm}

The original glandless germplasm lines and their selections were advanced to several replicated field tests in Las Cruces, NM, United States (Zhang et al., 2014a). Among the selections, most lines produced lint yields less than $70 \%$ of the Acala $1517-08$, and three selections within three lines (Acala G8160, SA 2455, and Acala GLS) brought the yield up to $82-89 \%$ of Acala $1517-08$. Therefore, there existed a significant yield gap (i.e., ca. 10-20\%) 
between the best glandless germplasm and commercial cotton. Furthermore, significant differences in fiber quality were found between selections within the same glandless germplasm lines, indicating genetic variation in fiber quality traits. The results indicated that residual genetic variation still existed, although most of the glandless germplasm lines were developed through pedigree selections from different cross combinations.

Meredith and Bridge (1982) estimated that the US national mean genetic gain in cotton yield improvement was $0.74 \%$ per year. For the New Mexico Cotton Breeding Program, the cotton yield gain due to breeding was $1.4 \%$ per year between 1930 and 2004 (Zhang et al., 2005, 2019a). Thus, it would take 713 years of breeding efforts to fill this $10-20 \%$ yield gap, i.e., to bring the yield up to the current level of glanded commercial cultivars. This is a difficult task because genetic improvement in lint yield still will be made for glanded commercial cotton by seed companies.

\section{Crossbreeding for Glandless Upland Cotton}

In 2010-2011, cross-breeding for glandless Upland cotton was initiated by crossing Acala 1517 with obsolete glandless cotton. In 2012, 35 new glandless lines were tested in a replicated trial in Las Cruces, NM. Approximately 70 exotic glandless lines were collected and grown in the field with selections made. In 2013, 150 new glandless breeding lines were evaluated in several replicated field tests. In 2014, tests on new glandless lines were performed at three locations (Las Cruces, Artesia, and Tucumcari) in New Mexico and 14 locations across the Cotton Belt. In the greenhouse, the 150 new glandless lines tested in the field in 2013 were evaluated for thrips and Verticillium wilt resistance. Under both the greenhouse and field conditions, 30 glandless lines plus two glanded checks were also tested for Verticillium wilt resistance. In 2015, several new glandless lines were tested at 14 locations across the Cotton Belt and also in three locations in New Mexico (Las Cruces, Artesia, and Tucumcari). Two replicated field tests were further performed in both Las Cruces and Artesia with each test having 30 glandless lines and two glanded checks for field performance and Verticillium wilt resistance.

From 2016 to present, increased breeding activities for glandless cotton have continued, which included: (1) 400-600 progeny rows; (2) several replicated field tests with 32 lines each; and field and/or greenhouse tests for resistance to thrips, Verticillium wilt, FOV race 4, bacterial blights, cotton rust, and leaf spots on an annual basis. It should be pointed out that, all the field trials in New Mexico did not receive any insecticide applications including seed treatments since 2010, when pink bollworms, bollworms, and plant bugs did not cause significant lint yield losses.

Due to the $10-20 \%$ yield gap between the best high-yielding glandless cotton and current commercial cultivars, crossbreeding should be taken into consideration to significantly increase the yield potential of glandless cotton so its potential as a triple-purpose crop can be fully realized. In the New Mexico Cotton Breeding Program, the glanded Acala 1517-08 cotton was first used to cross with the glandless Acala GLS, followed by repeated pedigree selections (Zhang et al., 2016a). Eighteen glandless individuals were first selected from $500 \mathrm{~F}_{2}$ plants and tested in $\mathrm{F}_{3}$ progeny rows, which were used as a base population for further single plant selections, followed by a progeny test. In the end, $77 \mathrm{~F}_{6}$ lines were selected for further replicated field testing. Five lines produced $90-96 \%$ of the Acala 1517-08 lint yield. There was no positive transgressive segregation for lint yield, lint percentage, and boll weight in this Acala/Acala cross because negative transgressive segregations occurred frequently for the three traits and fiber strength. Negative transgressive segregations occurred more frequently although positive transgressive segregation was observed for lint yield and micronaire.

The above Acala/Acala cross resulted in the development of the long-staple glandless Upland cultivar Acala 1517-18 GLS from an $\mathrm{F}_{4: 6}$ line, which carries the double recessive glandless genes $g l_{2} g l_{2} g l_{3} g l_{3}$ (Zhang et al., 2019c). In the cultivar release notice, Zhang et al. (2019c) summarized its field performance, as following: "This new glandless cultivar was tested in 11 replicated field trials in New Mexico in 2013-2016 and 14 tests across 11 US states in 2015. Acala 1517-18 GLS produced 93\% of the lint yield in Acala 1517-08 across all the tests without observed seed-cotton losses from rodents." But it yielded 30\% more lint than Acala GLS. Acala 1517-18 GLS had a similar fiber quality with Acala 1517-08 and Acala GLS in fiber length, uniformity, strength, and micronaire, but had a similar or higher elongation and similar or lower short fiber content. In addition to the higher seed index, Acala 1517-18 GLS had longer and stronger fibers, higher fiber length uniformity and elongation, but lower micronaire and short fiber content than most of the other medium-staple commercial checks. As compared to Acala 1517-08, it was more resistant to Alternaria leaf spots and had a similar or higher level of resistance to Verticillium wilt. Acala 1517-18 GLS represent the first contemporary longstaple (with fiber length $>30 \mathrm{~mm}$ ) Acala cotton cultivar with the glandless trait.

\section{Introgression Breeding for Glandless Upland Cotton}

Since the rediscovery of the Mendelian Laws in genetics in 1900, interspecific introgression genetics and breeding between Upland and Pima cotton (G. barbadense) have been extensively conducted by numerous scientists (Zhang et al., 2014e). However, only a few, if any, commercial cultivars were developed from this approach, due to the hybrid breakdown between the two closely related cultivated tetraploid cotton species. The hybrid breakdown is the reduced hybrid viability and/or fertility segregating in $\mathrm{F}_{2}$ and later generations, due to the complementary effects of numerous recessive genes from the two parental species. Under field conditions, almost no plants from an interspecific cross exhibited similar productivity with both its parents. In a genetic sense, the hybrid breakdown is transgressive segregation in a negative direction. Therefore, a breeder should first mitigate the hybrid breakdown caused by the negative transgressive segregation. Since 1985, J. Zhang has been working 
on introgression genetics and breeding in cotton (Zhang, 2011; Zhang et al., 2014e). As a result of the long-term effort, two glandless Upland cultivars, namely, NuMex COT 15 GLS and NuMex COT 17 GLS with FOV race 4 resistance, were developed and released from the advanced backcrossing between Upland and dominant glandless G. barbadense (Zhang et al., 2016b, 2020b). The release of the two NuMex COT cultivars represented the first successful attempt in introducing incomplete dominant glandless allele $\mathrm{Gl}_{2}{ }^{e}$ from G. barbadense to Upland cotton and developing commercial cultivars with acceptable yield and fiber quality characteristics in the US. The Brownfield Seed \& Delinting Company (BS\&D) in west Texas listed Acala 1517-18 GLS and NuMex COT 17 GLS (listed as Acala 1117) for seed sale. ${ }^{3}$ The two NuMex COT glandless cultivars were the result of a long-term effort of introgression breeding in transferring desirable genes and traits from Pima to Upland cotton.

Both NuMex COT 15 GLS and NuMex COT 17 GLS have the same pedigree, "derived from an advanced backcross progeny of a cross between the $\mathrm{Gl}_{2}{ }^{e}$ allele donor "Bahtim 110" (G. barbadense) and glanded Upland cotton CRI 12, followed by five backcrosses with a glanded Upland CRI 35 as the recurrent parent" (Zhang et al., 2016b, 2020b). In the advanced backcross population, they were selected as two glandless progenies out of a mixture of glandless and glanded plants. When evaluated in two naturally infected fields in California, the two cultivars were resistant to FOV race 4, with resistance levels similar to the resistant checks- Pima PHY 802 RF and PHY 811 RF. $^{4}$ However, they were more resistant than Acala 1517-08, when evaluated in a greenhouse in New Mexico. The two cultivars have been used in crossbreeding to developing new germplasm lines to build resistance to FOV race 4 (Ulloa et al., 2020). The two cultivars were tested in 4-7 replicated field trials in New Mexico in 2013-2017 and 11 tests across 9 US states in 2014. Both cultivars yielded more lint than Acala GLS, and NuMex COT 17 GLS yielded more than NuMex COT 15 GLS as it produced 16 and 13\% more lint yields than Acala 1517-18 GLS, and NuMex COT 15 GLS, respectively, and reached $93 \%$ of the yield of the glanded Acala 1517-08. Both were classified as having medium to long staples with a fiber quality similar to other commercial medium staple cultivars, but inferior to both Acala cultivars. NuMex COT 15 GLS had longer and stronger fibers than NuMex COT 17 GLS, but the latter had a higher lint percentage and was specially adapted to the Mississippi Delta because it was the top yielder in the region. The two glandless cultivars responded to thrips and Verticillium wilt similarly to Acala 1517-08 but were less susceptible to Alternaria leaf spots. NuMex COT 17 GLS was resistant to four races including race 18 of bacterial blights (see text footnote 4 ). The high yield potential of NuMex COT 17 GLS, together with other glandless lines, was evaluated in different soil types and under different crop management practices such as planting date, nitrogen rate, potassium application, deficit irrigation, and reduced tillage in New Mexico (Idowu et al., 2013b, 2015, 2016, 2018; Sultana et al., 2018).

${ }^{3}$ www.brownfieldseed.com

${ }^{4}$ https://rbtn.cottoninc.com

\section{PERSPECTIVE}

Glandless cotton (conditioned by two recessive genes, $g l_{2} g l_{3}$ ) had received great attention in the US between the 1960s and the 1970s after its first discovery by McMichael (1959). During this period, most of the public breeding and genetic programs were involved in developing glandless Upland cotton lines or cultivars, resulting in the development of numerous improved glandless lines and a few commercial cultivars. The two glandless genes were also transferred into Pima cotton through interspecific crossings and backcrossings. Because of the unusually high insect pressure associated with glandless cotton, many breeders and geneticists developed NILs with glanded and glandless traits through backcrossing to study the genetic efforts of the two glandless genes on yield, fiber, and seed quality in Upland cotton, and its responses to insects. There appears to be no direct genetic association between glandless genes and responses to diseases, nematodes, and abiotic stresses. Through collaborations between entomologists and cotton breeders, extensive field, greenhouse, and laboratory studies were conducted to compare the susceptibilities to insect pests between glandless and glanded cotton under similar genetic backgrounds. As compared with glandless cotton, larvae of boll weevils, bollworms, and armyworms have developed an avoidance mechanism to avoid glands or gossypol-rich young leaves while searching for food, and they, therefore, feed less and rest more on glanded cotton. Thus, these and other insect pests grow faster and gain more bodyweight with higher survival rates and shortened time to pupation as adults on glandless cotton. In some genetic backgrounds, no significant differences in the susceptibility to boll weevils and bollworms/budworms were observed between glandless and glanded NILs under field conditions, due likely to some unknown genetic resistance factors that could compensate or alleviate the susceptibility of glandless cotton. This led breeders to search for traits or genetic factors to be used to alleviate the susceptibility to insects in glandless cotton. For example, the plant height, leaf color, growth characteristics, and an $\mathrm{X}$ genetic factor in a Sea-Island accession (G. barbadense) were found to confer resistance to boll weevils in glandless cotton. Glandless cotton possessing combinations of nectarilessness, hirsuteness, or rapid fruiting ability were less susceptible to plant bugs. However, these traits could still not provide adequate protection against major insect pests in both glanded and glandless cotton. Equally importantly, the market for seed processing and utilization was not developed to demand commercially grown glandless cotton in the 1970 and 1980s.

However, it is time to revitalize the breeding, research, and utilization of glandless cotton in the US and the world. First of all, the current cotton production conditions are greatly different from 10 to 20 years ago. Boll weevils and pink bollworms are no longer a production issue in the US because of successful eradication programs. After more than 25 years of the commercial production of Bt cotton in the US and its widespread use in other cotton-producing countries, Helicoverpa spp. including budworms, earworms, bollworms, and other lepidopteran pests are under effective control. 
Plant bugs, aphids, and spider mites are not major pests in many cotton production regions; and usually, thrips do not need chemical controls because cotton seedlings can outgrow their damage. Second, there are more amendable genetic sources of glandless cotton such as the dominant glandless trait $\left(G_{2}{ }^{e}\right)$, transgenic cotton, producing ULGCS, and non-transgenic glandless cotton through genome editing, in addition to the double recessive glandless trait that was most extensively studied. However, due to the lack of breeding activities in developing commercially competitive glandless cotton, the large yield gap between the best glandless cotton and current commercial cultivars has prevented farmers from growing glandless cotton. Therefore, it is urgently imperative that more breeders and geneticists are engaged in the effort to use different sources of glandless traits and to develop elite and commercial highyielding glandless cotton with good fiber quality and resistance

\section{REFERENCES}

Abdelraheem, A., Liu, F., Song, M., and Zhang, J. F. (2017). A meta-analysis of quantitative trait loci for abiotic and biotic stress resistance in tetraploid cotton. Mol. Genet. Genomics 292, 1221-1235. doi: 10.1007/s00438-017-1342-0

Afifi, A., Bary, A. A., Kamel, S. A., and Heikal, I. (1966). Bahtim 110, a new strain of Egyptian cotton free from gossypol. Empire Cotton Grow Rev. 43, 112-120.

Anderson, D. C., Jonsson, M., and Morte, U. (2001). Variation in damage to cotton affecting larval feeding preference of Spodoptera littoralis. Entomol. Exp. Appl. 101, 191-198. doi: 10.1046/j.1570-7458.2001.00903.x

Anonymous (1978). Proceedings of Glandless Cotton: Its Significance, Status and Prospects, U.S. Department of Agriculture. Beltsville, MD: Agricultural Research Service, 1978.

Atkins, F. M., Wilson, M., and Bock, S. A. (1988). Cottonseed hypersensitivity: new concerns over an old problem. J. Allergy Clin. Immunol. 82, 242-250. doi: 10.1016/0091-6749(88)91006-8

Bailey, J. C., and Meredith, W. R. Jr. (1983). Resistance of cotton, Gossypium hirsutum L., to natural field populations of twospotted spider mites (Acari: Tetranychidae). Environ. Entom. 12, 763-764. doi: 10.1093/ee/12.3.763

Baloch, A. A., Soomro, B. A., and Mallah, G. H. (1982). Evaluation of some cotton varieties with known genetic markers for their resistance/tolerance against sucking and bollworm complex. Turkiye Bitki Koruma Dergisi 6, 3-14.

Belcher, D. W., Schneider, J. C., Hedin, P. A., and French, J. C. (1983). Impact of glands in cotton anthers on feeding behavior of Heliothis virescens (F.) (Lepidoptera: Noctuidae) larvae. Environ. Entomol. 12, 1478-1481. doi: 10. 1093/ee/12.5.1478

Benedict, J. H., Leigh, T. F., Frazier, J. L., and Hyer, A. H. (1981). Ovipositional behavior of Lygus hesperus on two cotton genotypes. Ann. Entomol. Soc. Amer. 74, 392-394. doi: 10.1093/aesa/74.4.392

Benedict, J. H., Leigh, T. F., Tingey, W., and Hyer, A. H. (1977). Glandless Acala cotton: more susceptible to insects. Calif Agric. 31, 14-15.

Benedict, J. H., Sachs, E. S., Altman, D. W., Ring, D. R., De Spain, R. R., and Lawlor, D. J. (1993). Resistance of glandless transgenic Bt cotton to injury from tobacco budworm. Proc. Beltwide Cotton Conf. 1993, 814-816.

Bhatnagar, P., and Sharma, P. D. (1991). Comparative incidence of sucking insect pests on different isogenic lines of cotton variety H777. J. Insect. Sci. 4, 170-171.

Bi, I. V., Maquet, A., Baudoin, J. P., du Jardin, P., Jacquemin, J. M., and Mergeai, G. (1999). Breeding for" low-gossypol seed and high-gossypol plants" in upland cotton. Analysis of tri-species hybrids and backcross progenies using AFLPs and mapped RFLPs. Theor. Appl. Genet 99, 1233-1244. doi: 10.1007/s001220051329

Bottger, G. T., Sheehan, E. T., and Lukefahr, M. J. (1964). Relation of gossypol content of cotton plants to insect resistance. J. Econ. Entomol. 57, 283-285. doi: 10.1093/jee/57.2.283

Buford, W. T., Jenkins, J. N., and Maxwell, F. G. (1968). A boll weevil oviposition suppression factor in cotton. Crop. Sci. 8, 647-649. doi: 10.2135/cropsci1968. 0011183x000800060002x to insects and diseases. Glandless traits should be introduced into commercial cultivars with insect-resistant Bt and herbicidetolerant cotton.

\section{AUTHOR CONTRIBUTIONS}

JZ drafted the manuscript. TW edited and approved the final manuscript. Both authors contributed to the article and approved the submitted version.

\section{FUNDING}

This research has been supported in part by Cotton Incorporated and New Mexico Agricultural Experiment Station.

Calhoun, D. (1997). Inheritance of high glanding, an insect resistance trait in cotton. Crop. Sci. 37, 1181-1186. doi: 10.2135/cropsci1997. 0011183x003700040026x

Cantrell, R. G., Robert, C. L., and Waddell, C. (2000). Registration of 'Acala 1517-99' cotton. Crop. Sci. 30, 1200-1201. doi: 10.2135/cropsci2000.0049rcv

Cheng, H., Lu, C., Yu, J. Z., Zou, C., Zhang, Y., Wang, Q., et al. (2016). Fine mapping and candidate gene analysis of the dominant glandless gene $G_{2}{ }^{e}$ in cotton (Gossypium spp.). Theor. Appl. Genet. 129, 1347-1355. doi: 10.1007/ s00122-016-2707-1

Cherry, J. P. (1983). Cottonseed oil. J. Am. Oil Chem. Soc. 60, 360-367.

Cherry, J. P., Kohel, R. J., Jones, L. A., and Powell, W. H. (1981). "Cottonseed quality: factors affecting feed and food uses," in Proceeding Beltwide Cotton Production Research Conference, ed. J. M. Brown (Memphis: National Cotton Council), 266-282.

Cherry, J. P., and Leffler, H. R. (1984). "Seed”, in Cotton, Agronomy Monograph, eds R. J. Kohel and C. F. Lewis (Madison: Crop Science Society of America), 511-531.

Cherry, J. P., Simmons, J. G., and Kohel, R. J. (1978). "Potential for improving cottonseed quality by genetics and agronomic practices," in Nutritional Improvement of Food and Feed Proteins, ed. M. Friedman (New York: Plenum Press), 343-364. doi: 10.1007/978-1-4684-3366-1_18

De Carvalho, L. P., and De Macedo Vieira, R. (2000). Expression of Gossypium barbadense $\mathrm{Gl}_{2}{ }^{e}$ gene, in Gossypium hirsutum annual cotton. Proc. Beltwide Cotton Conf. 4, 39-44.

Dobbs, J. H., and Oakley, S. R. (2000). "CPCSD Acala GLS: A glandless cotton variety for the San Joaquin Valley," in Proceedings Beltwide Cotton Conference, (San Antonio, TX: Natl Cotton Counc Am), 115-118.

Dong, C. C., Ding, Y. Z., Guo, W. Z., and Zhang, T. Z. (2007). Fine mapping of the dominant glandless gene $\mathrm{Gl}_{2}{ }^{e}$ in Sea-island cotton (Gossypium barbadense L.). Chin. Sci. Bull. 52, 3105-3109. doi: 10.1007/s11434-007-0468-6

Ellington, J., Cardenas, M., Kiser, K., Guerra, L., Salguero, V., and Ferguson, G. (1984). Approach to the evaluation of some factors affecting insect resistance in one 'Acala' and seven sister genotypes of Stoneville cotton in New Mexico. J. Econ. Entomol. 77, 612-618. doi: 10.1093/jee/77.3.612

Elzen, G. W., Williams, H. J., Bell, A. A., Stipanovic, R. D., and Vinson, S. B. (1985). Quantification of volatile terpenes of glanded and glandless Gossypium hirsutum L. cultivars and lines by gas chromatography. J. Agric. Food. Chem. 33, 1079-1082. doi: 10.1021/jf00066a015

Endrizi, J. E., Turcotte, E. L., and Kohel, R. J. (1985). Genetics, cytology, and evolution of Gossypium. Adv. Genet. 23, 271-375. doi: 10.1016/s0065-2660(08) 60515-5

Fang, W. P., Wu, Z. D., Wu, Y. F., and Wc. (1995). Advances in Chinese glandless cotton research. Sci. Agric. Sin. 28, 61-69.

Foster, J. D. Jr., Verhalen, L. M., and Murray, D. S. (1994). Prometryn tolerance in glanded versus glandless isolines of cotton. Crop. Sci. 34, 67-71. doi: 10.2135/ cropsci1994.0011183x003400010012x 
Gao, W., Xu, F. C., Lu, L., Li, Y., Zhang, J. L., Chong, L., et al. (2020). The gland localized CGP1 controls gland pigmentation and gossypol accumulation in cotton. Plant Biotechnol. J. 18, 1573-1584. doi: 10.1111/pbi.13323

Garnett, A., Pierce, J. B., Monk, P. E., Idowu, O. J., and Flynn, R. P. (2013). "Glandless cotton in New Mexico: Impact of nitrogen on gossypol associated resistance to cotton bollworm and beet armyworm," in Proccedings Beltwide Cotton Conference, (San Antonio, TX: National Cotton Council), 432-435.

Goodell, P. B., Garcia, C. M., Keillor, K. D., Haas, C., Godfrey, L. D., and Munk, D. (2001). Influence of cotton varieties on arthropod fauna. Proc. Beltwide Cotton Conf. 2001, 1019-1021.

Gutiérrez, O. A., Bowman, D. T., Cole, C. B., Jenkins, J. N., McCarty, J. C. Jr., Wu, J. X., et al. (2006). Development of random-mated populations using bulked pollen methodology: cotton as a model. J. Cotton Sci. 10, 175-179.

Hagenbucher, S., Eisenring, M., Meissle, M., Rathore, K. S., and Romeis, J. (2019). Constitutive and induced insect resistance in RNAi-mediated ultra-low gossypol cottonseed cotton. BMC Plant Biol. 19:322. doi: 10.1186/s12870-0191921-9

Halloin, J. M., Turner, J. H. Jr., and Hoskinson, P. E. (1978). Comparison of seed and fiber properties and yield of glanded and glandless cottons. Crop Sci. 18, 519-520. doi: 10.2135/cropsci1978.0011183x001800030048x

Hau, B. (1987). "Development of glandless cotton in Africa," in Proceedings. Beltwide Cotton Production Research Conferences. Dugger, (Memphis: NCCA), $125-126$.

Hinze, L., and Kohel, R. J. (2012). "Chapter 9 Cotton,” in Technical Renovations in Major World Oilseed Crops, Vol I Breeding, ed. S. K. Gupta (New York, NY: Springer), 226-228.

Hinze, L. L., and Kohel, R. J. (2006). Evaluation of a commercial ELISA kit for quantifying CRY1ac production in glandless cotton. Proc. Beltwide Cotton Conf. $85,774-779$.

Hinze, L. L., Kohel, R. J., Campbell, B. T., and Percy, R. G. (2014). Registration of four diverse random-mated cotton germplasm populations. J. Plant Reg. 8, 57-62. doi: 10.3198/jpr2013.06.0027crg

Idowu, J., Pierce, J., Bundy, S., Zhang, J. F., Flynn, R., Carrillo, T., et al. (2012). Evaluation of glandless cotton cultivars in New Mexico. Proc. Beltwide Cotton Conf. 2012, 90-94.

Idowu, J., Zhang, J. F., Flynn, R., Pierce, J., Carrillo, T., Bundy, S., et al. (2011). Yield potential, fiber quality and adaptability of glandless cotton in New Mexico. Proc. Beltwide Cotton Conf. 2011, 89-93.

Idowu, J., Zhang, J. F., Pierce, J., Omer, M., and Wedegaertner, T. (2018). “Impacts of potassium fertilization on new glandless cotton cultivars developed for New Mexico," in Beltwide Cotton Conferences, (Mexico: New Mexico State University), 153-156.

Idowu, O. J., Flynn, R. P., Pierce, J. B., Zhang, J. F., Scheffler, J., and Wedegaertner, T. (2013a). Evaluation of three cultivars of glandless cotton in New Mexico. Proc. Beltwide Cotton Conf. 2013, 87-89.

Idowu, O. J., Flynn, R. P., Pierce, J. B., Zhang, J., and Wedegaertner, T. C. (2013b). Planting date and fertilizer rate effects on selected cotton cultivars in New Mexico. Proc. Beltwide Cotton Conf. 2013, 90-93.

Idowu, O. J., Zhang, J. F., Flynn, R. F., Pierce, J. B., and Wedegaertner, T. (2014). Comparative performance of a glandless Acala cultivar and two glanded Acala cultivars in New Mexico. J. Cotton Sci. 18, 122-128.

Idowu, O. J., Zhang, J. F., Pierce, J. B., Flynn, R. B., and Wedegaertner, T. C. (2015). Impact of deficit irrigation on selected glandless cultivars in New Mexico. Proc. Beltwide Cotton Conf. 2015, 160-163.

Idowu, O. J., Zhang, J. F., Pierce, J. B., Flynn, R. B., and Wedegaertner, T. C. (2016). Performance of new glandless cotton lines as a function of soil type and nitrogen rates. Proc Beltwide Cotton Conf. 2016, 58-61.

Janga, M. R., Pandeya, D., Campbell, L. M., Konganti, K., Villafuerte, S. T., Puckhaber, L., et al. (2019). Genes regulating gland development in the cotton plant. Plant Biotechnol. J. 17, 1142-1153. doi: 10.1111/pbi.13044

Jenkins, J. N., Maxwell, F. G., and Lafever, H. N. (1966). The comparative preference of insects for glanded and glandless cottons. J. Econ. Entomol. 59, 352-356. doi: 10.1093/jee/59.2.352

Jenkins, J. N., Maxwell, F. G., and Parrott, W. L. (1967). Field Evaluation of glanded and glandless cotton (Gossypium hirsutum L.) lines for boll weevil (Anthonomus grandis Boh.) susceptibility. Crop Sci. 7, 437-440. doi: 10.2135/cropsci1967. 0011183x000700050009x

Khoshkhoo, N., Hedin, P. A., and McCarty, J. C. Jr. (1994). Terpenoid aldehydes in root-knot nematode susceptible and resistant cotton plants. J. Agric. Food Chem. 42, 204-208. doi: 10.1021/jf00037a037
Kohel, R. J. (1979). Gene arrangement in the duplicate linkage groups V and IX: nectariless, glandless, and withering bract in cotton. Crop Sci. 19, 831-833. doi: 10.2135/cropsci1979.0011183x001900060021x

Kohel, R. J., and Lee, J. A. (1984). Genetic analysis of Egyptian glandless cotton. Crop Sci. 24, 1119-1121. doi: 10.2135/cropsci1984.0011183x002400060027x

Kong, G., Dauda, M. K., and Zhu, S. (2010). Effects of pigment glands and gossypol on growth, development and insecticide-resistance of cotton bollworm (Heliothis armigera (Hübner)). Crop Prot. 29, 813-819. doi: 10.1016/ j.cropro.2010.03.016

Larson, Z. J. (2019). Evaluation of new glandless Upland cotton lines for resistance to thrips and Verticillium wilt. $\mathrm{Ph} \mathrm{D}$, thesis, Mexico: New Mexico State University.

Larson, Z. J., Barrick, B., Abdelraheem, A., Sanogo, S., Pierce, J., Flynn, R., et al. (2015). Evaluation of new glandless cotton lines for thrips and Verticillium wilt resistance. Proc. Beltwide Cotton Conf. 2015:357.

Lee, J. A. (1965). The genomic allocation of the principal foliar-gland loci in Gossypium hirsutum and Gossypium barbadense. Evolution 19, 182-188. doi: $10.2307 / 2406373$

Lee, J. A. (1978). Inheritance of gossypol level in Gossypium. IV. Results from the reciprocal exchange of the major gossypol-gland alleles between G. hirsutum L. and G. barbadense L. Crop Sci. 18, 482-484. doi: 10.2135/cropsci1978. 0011183x001800030032x

Leigh, T. F., Hyer, A. H., Benedict, J. H., and Wynholds, P. F. (1985). Observed population increase, nymphal weight gain, and oviposition nonpreference as indicators of Lygus hesperus Knight (Heteroptera: Miridae) resistance in glandless cotton. J. Econ. Entomol. 78, 1109-1113. doi: 10.1093/jee/78.5.1109

Li, B., Liang, S., Alariqi, M., Wang, F., Wang, G., Wang, Q., et al. (2021). The application of temperature sensitivity CRISPR/LbCpf1 (LbCas12a) mediated genome editing in allotetraploid cotton (G. hirsutum) and creation of nontransgenic, gossypol-free cotton. Plant Biotechnol. J. 19, 221-223. doi: 10. $1111 /$ pbi. 13470

Li, S. Q., Liu, A. Y., Kong, L. L., Gong, J. W., Li, J. W., Gong, W. K., et al. (2019). QTL mapping and genetic effect of chromosome segment substitution lines with excellent fiber quality from Gossypium hirsutum $\times$ Gossypium barbadense. Mol. Genet Genomics 294, 1123-1136. doi: 10.1007/s00438-019-01566-8

Liu, Q., Wang, Y., Chen, J., Zhang, T. Z., and Zhou, B. (2015). A New Synthetic allotetraploid (A1A1G2G2) between Gossypium herbaceum and G. australe: Bridging for simultaneously transferring favorable genes from these two diploid species into upland cotton. PLoS One 10, e0123209. doi: 10.1371/journal.pone. 0123209

Lukefahr, M. J., and Houghtaling, J. E. (1969). Resistance of cotton strains with high gossypol content to Heliothis spp. J. Econ. Entomol. 62, 588-591. doi: $10.1093 /$ jee/62.3.588

Lukefahr, M. J., Noble, L. W., and Houghtaling, J. E. (1966). growth and infestation of bollworms and other insects on glanded and glandless strains of cotton. J. Econ. Entomol. 59, 817-820. doi: 10.1093/jee/59.4.817

Lusas, E. W., and Jividen, G. M. (1987). Glandless cottonseed: A review of the first 25 years of processing and utilization research. J. Amer. Oil Chem. Soc. 64, 839-854. doi: 10.1007/bf02641491

Ma, D., Hu, Y., Yang, C., Liu, B., Fang, L., Wan, Q., et al. (2016). Genetic basis for glandular trichome formation in cotton. Nat. Commun. 7:10456.

Maxwell, F. G., Lafever, H. N., and Jenkins, J. N. (1965). Blister beetles on glandless cotton. J. Econ. Entomol. 58, 792-793. doi: 10.1093/jee/58.4.792

Maxwell, F. G., Lafever, H. N., and Jenkins, J. N. (1966). Influence of the glandless genes in cotton on feeding, oviposition, and development of the boll weevil in the laboratory. J. Econ. Entomol. 59, 585-588. doi: 10.1093/jee/59.3.585

McAuslane, H. J., and Alborn, H. T. (2000). Influence of previous herbivory on behavior and development of Spodoptera exigua larvae on glanded and glandless cotton. Entomol. Exp. Appl. 97, 283-291. doi: 10.1046/j.1570-7458.2000.00741.x

McAuslane, H. J., and Alborn, T. (1998). Systemic induction of allelochemicals in glanded and glandless isogenic cotton by Spodoptera exigua feeding. J. Chem. Ecol. 24, 399-416.

McCarty, J. C. Jr., Meredith, W. R., Jenkins, J. N., Parrott, W. L., and Bailey, J. C. (1983). Genotype X environment interaction of cottons varying in insect resistance. Crop Sci. 23, 970-973. doi: 10.2135/cropsci1983. 0011183x002300050037x

McMichael, S. C. (1959). Hopi cotton, a source of cottonseed free of gossypol pigments. Agron. J. 51:663.

McMichael, S. C. (1960). Combined effects of glandless genes g12 and g13 on pigment glands in the cotton plant. Agron. J. 52, 385-386. doi: 10.2134/ agronj1960.00021962005200070005x 
Meisner, J., Zur, M., Kabonci, E., and Ascher, K. R. S. (1977c). Influence of gossypol content of leaves of different cotton strains on the development of Spodoptera littoralis larvae. J. Econ. Entomol. 70, 714-716. doi: 10.1093/jee/70.6.714

Meisner, J., Ascher, K. R. S., and Zur, M. (1977a). Phagodeterrency induced by pure gossypol and leaf extracts of a cotton strain with high gossypol content in the larva of Spodoptera littoralis. J. Econ. Entomol. 70, 149-150. doi: 10.1093/jee/70. 1.149

Meisner, J., Ascher, K. R. S., Zur, M., and Kabonci, E. (1977b). Synergistic and antagonistic effects of gossypol for phosfolan in Spodoptera littoralis larvae on cotton leaves. J. Econ. Entomol. 70, 717-719. doi: 10.1093/jee/70.6.717

Meredith, W. R. Jr., and Bridge, R. R. (1982). "Genetic contributions to yield changes in cotton," in Genetic Contributions to Yield Gains of Five Major Crop Plants, ed. W. R. Fehr (Madison, WI: CSSA), 75-87. doi: 10.2135/cssaspecpub7. c4

Meredith, W. R. Jr., Hanny, B. W., and Bailey, J. C. (1979). Genetic variability among glandless cottons for resistance to two insects. Crop Sci. 19, 651-653. doi: 10.2135/cropsci1979.0011183x001900050026x

Merkl, M. E., and Meyer, J. R. (1963). Studies of resistance of cotton strains to the boll weevil. J. Econ. Entomol. 56, 860-862.

Montandon, R., Stipanovic, R. D., Williams, H. J., Sterling, W. L., and Vinson, S. B. (1987). Nutritional indices and excretion of gossypol by Alabama argillacea (Hübner) and Heliothis virescens (F.) (Lepidoptera: Noctuidae) fed glanded and glandless cotyledonary cotton leaves. J. Econ. Entomol. 80, 32-36. doi: 10.1093/jee/80.1.32

Montandon, R., Williams, H. J., Sterling, W. L., Stipanovic, R. D., and Vinson, S. B. (1986). Comparison of the development of Alabama argillacea (Hübner) and Heliothis virescens (F.) (Lepidoptera: Noctuidae) fed glanded and glandless cotton leaves. Environ. Entomol. 15, 128-131. doi: 10.1093/ee/15.1.128

Mullins, W., and Pieters, E. P. (1982). Effect of resistant and susceptible cotton strains on larval size, developmental time, and survival of the tobacco budworm. Environ. Entomol. 11, 363-366.

O’Brien, R. D., Jones, L. A., King, C. C., Wakelyn, P. J., and Wan, P. J. (2005). "Cottonseed oil," in Bailey's Industrial Oil and Fat Products, 6th Edn, ed. F. Shahidi (New Jersey: Wiley).

Oliver, B. F., Maxwell, F. G., and Jenkins, J. N. (1970a). A comparison of the damage done by the bollworm to glanded and glandless cottons. J. Econ. Entomol. 63, 1328-1329. doi: 10.1093/jee/63.4.1328

Oliver, B. F., Maxwell, F. G., and Jenkins, J. N. (1970b). Utilization of glanded and glandless cotton diets by the bollworm. J. Econ. Entomol. 63, 1965-1966.

Oliver, B. F., Maxwell, F. G., and Jenkins, J. N. (1971). Growth of the bollworm on glanded and glandless cottons. J. Econ. Entomol. 64, 396-398. doi: 10.1093/jee/ 64.2.396

Owen, D. F., and Gannaway, J. R. (1995). Twelve glandless cotton germplasms. Crop Sci. 35:1515.

Palle, R. A., Campbell, L., Pandeya, D., Puckhaber, L., Tollack, L. K., Marcel, S., et al. (2013). RNAi-mediated ultra-low gossypol cottonseed trait: performance of transgenic lines under field conditions. Plant Biotech. J. 11, 296-304.

Parrott, W. L. (1990). Plant resistance to insects in cotton. Florida Entomol. 73, 392-410. doi: $10.2307 / 3495457$

Parrott, W. L., Jenkins, J. N., and McCarty, J. C. Jr. (1983). Feeding behavior of firststage tobacco budworm (Lepidoptera: Noctuidae) on three cotton cultivars. Ann. Entomol. Soc. Am. 76, 167-170. doi: 10.1093/aesa/76.2.167

Pierce, J. B., Garnett, A., and Monk, P. E. (2012). Glandless cotton in New Mexico: weighing the risk of insect losses. Proc. Beltwide Cotton Conf. 2012, 904-908.

Pierce, J. B., Monk, P. E., Garnett, A., Flynn, R., and Idowu, J. (2014). "Glandless cotton in New Mexico: Beet armyworm, Spodoptera exigua and bollworm, Helicoverpa zea development and field damage," in Proceedings Beltwide Cotton Conference National Cotton Council, (New Orleans), 2014, 688-692.

Pierce, J. B., Monk, P. E., Garnett, A., and Idowu, J. (2015). "Predation of sentinel bollworm eggs in glanded and glandless cotton in New Mexico," in Proceedings Beltwide Cotton Conference National Cotton Council, (New Orleans, LA), 2015, 278-282.

Pierce, J. B., Monk, P. E., Garnett, A., Richman, D., and Idowu, J. (2016). "Control of insect pests in glandless cotton: The role of biological control in New Mexico," in Proceedings Beltwide Cotton Conference National Cotton Council, (New Orleans, LA), 2016, 198-201.

Pierce, J. B., Monk, P. E., and Idowu, J. (2017). "Predation of sentinel eggs in cotton and sorghum in New Mexico," in Proceedings Beltwide Cotton Conference National Cotton Council, (New Orleans, LA), 2017, 536-541.
Quisenberry, J. E., and Rummel, D. R. (1979). Natural resistance to thrips injury in cotton as measured by differential leaf area reduction. Crop Sci. 19, 879-881. doi: $10.2135 /$ cropsci1979.0011183x001900060032x

Rathore, K. S., Pandeya, D., Campbell, L. M., Wedegaertner, T. C., Puckhaber, L., Stipanovic, R. D., et al. (2020). Ultra-low gossypol cottonseed: selective gene silencing opens up a vast resource of plant-based protein to improve human nutrition. Crit. Rev. Plant Sci. 39, 1-29. doi: 10.1080/07352689.2020.1724433

Rathore, K. S., Sundaram, S., Sunilkumar, G., Campbell, L., Puckhaber, L., Marcel, S., et al. (2012). Ultra-low gossypol cottonseed: generational stability of the seed-specific, RNAi-mediated phenotype and resumption of terpenoid profile following seed germination. Plant Biotech. J. 10, 174-183. doi: 10.1111/j.14677652.2011.00652.x

Rizwan, M., Abro, S., Asif, M. U., Hameed, A., Mahboob, W., Deho, Z. A., et al. (2021). Evaluation of cotton germplasm for morphological and biochemical host plant resistance traits against sucking insect pests complex. J. Cotton Res. $4: 18$.

Rummel, D. R., and Quisenberry, J. E. (1979). Influence of thrips injury on leaf development and yield of various cotton genotypes. J. Econ. Entomol. 72, 706-709.

Scheffler, J. A., and Romano, G. A. (2012). Registration of GVS1, GVS2, and GVS3 Upland cotton lines with varying gland densities and two near-isogenic lines, GVS4 and GVS5. J. Plant Reg. 6, 190-194. doi: 10.3198/jpr2011.10.0567crg

Scheffler, J. A., Romano, G. B., and Blanco, C. A. (2012). Evaluating host plant resistance in cotton (Gossypium hirsutum L.) with varying gland densities to tobacco budworm (Heliothis virescens F.) and bollworm (Helicoverpa zea Boddie) in the field and laboratory. Agric. Sci. 3:16845.

Schmidt, K. M., Benedict, J. H., and Walmsley, M. H. (1988). Behavioral responses (time budgets) of bollworm (Lepidoptera: Noctuidae) larvae for three cotton cultivars. Environ. Entomol. 17, 350-353. doi: 10.1093/ee/17.2.350

Schuster, M. F., Maxwell, F. G., and Jenkins, J. N. (1972). Resistance to the twospotted spider mite in certain Gossypium hirsutum races, Gossypium species, and glanded-glandless counterpart cottons. Environ. Entomol. 65, 1108-1110. doi: $10.1093 /$ jee/65.4.1108

Shaver, T. N., Dilday, R. H., and WilsonFD. (1980). Use of glandless breeding stocks to evaluate unknown heliothis growth inhibitors (X-factors) in cotton. Crop Sci. 20, 545-548. doi: 10.2135/cropsci1980.0011183x002000040032x

Shepherd, R. L. (1982). Registration of eight germplasm lines of glandless cotton (Reg. No. GP 202 to GP 209). Crop Sci. 22, 899-900. doi: 10.2135/cropsci1982. 0011183x002200040049x

Shi, Y., Liu, A., Li, J., Zhang, J., Zhang, B., Ge, Q., et al. (2019). Dissecting the genetic basis of fiber quality and yield traits in interspecific backcross populations of Gossypium hirsutum?×?Gossypium barbadense. Mol. Genet Genomics 294, 1385-1402. doi: 10.1007/s00438-019-01582-8

Shi, Y., Zhang, B., Liu, A., Li, W., Li, J., Lu, Q., et al. (2016). Quantitative trait loci analysis of Verticillium wilt resistance in interspecific backcross populations of Gossypium hirsutum?×?Gossypium barbadense. BMC Genomics 17:877. doi: 10.1186/s12864-016-3128-x

Silva, F. M., de, A., Penna, J. C. V., Forti, L. C., and de Santana, D. G. (2002). Occurrence of insect pests and their natural predators on glandless upland cotton genotypes. Biosci. J. 18, 31-39.

Singh, I. D., and Weaver, J. B. Jr. (1972). Growth and infestation of boll weevils on normal-glanded, glandless, and high-gossypol strains of cotton. J. Econ. Entomol. 65, 821-824. doi: 10.1093/jee/65.3.821

Smith, C. W., and Niles, G. A. (1988). Registration of fourteen cotton germplasm lines. Crop Sci. 28, 578-579. doi: 10.2135/cropsci1988.0011183x002800030042x

Stephens, S. G., and Lee, H. S. (1961). Further Studies on the Feeding and Oviposition Preferences of the Boll Weevil (Anthonomus grandis). J. Econ. Entomol. 54, 1085-1090. doi: 10.1093/jee/54.6.1085

Stipanovic, R. D., Lopez, J. D. Jr., Dowd, M. K., Puckhaber, L. S., and Duke, S. E. (2006). Effect of racemic and (+)- and (-)-gossypol on the survival and development of Helicoverpa zea larvae. J. Chem. Ecol. 32, 959-968. doi: 10.1007/ s10886-006-9052-9

Sultana, S., Idowu, O. J., Darapuneni, M., Zhang, J. F., Omer, M., and Wedegaertner, T. C. (2018). Reduced tillage effects on cotton growth and yield in New Mexico. Proc. Beltwide Cotton Conf. 2018, 79-82.

Sunilkumar, G., Campbell, L., Puckhaber, L., Stipanovic, R. D., and Rathore, K. S. (2006). Engineering cottonseed for use in human nutrition by tissue-specific reduction of toxic gossypol. Proc. Natl. Acad. Sci. U.S.A. 103, 18054-18059. doi: 10.1073/pnas.0605389103 
Tang, D., Feng, S., Li, S., Chen, Y., and Zhou, B. (2018). Ten alien chromosome additions of Gossypium hirsutum-Gossypium bickii developed by integrative uses of GISH and species-specific SSR markers. Mol. Genet Genomics 293, 945-955. doi: 10.1007/s00438-018-1434-5

Thaxton, P. M., El-Zik, K. M., Bird, L. S., Wallace, T. P., Cook, C. G., Benedict, J. H., et al. (1987). Progress in developing glandless multi-adversity resistant (MAR) cottons. Proc. Beltwide Cotton Conf. 1987, 551-554.

Thaxton, P. M., El-Zik, K. M., and Dusek, T. (1998). Development of MAR cotton germplasm with morphological mutant traits. Proc. Beltwide Cotton Conf. 98, 557-564.

Tian, X., Ruan, J. X., Huang, J. Q., Yang, C. Q., Fang, X., Chen, Z. W., et al. (2018). Characterization of gossypol biosynthetic pathway. Proc. Natl. Acad. Sci. U.S.A. 115, E5410-E5418.

Tingey, W. M., Leigh, T. F., and Hyer, A. H. (1975). Glandless cotton: susceptibility to Lygus hesperus Knight. Crop Sci. 15, 251-253. doi: 10.2135/cropscil 975 . 0011183x001500020032x

Ulloa, M., Hutmacher, R. B., Schramm, T. L., Ellis, M. L., Nichols, R., Roberts, P. A., et al. (2020). Sources, selection and breeding of Fusarium wilt (Fusarium oxysporum f. sp. vasinfectum) race 4 (FOV4) resistance in Upland (Gossypium hirsutum L.) cotton. Euphytica 216:109.

Wang, C., Yang, Q., and Zhou, M. (2008). Effects of gossypol on growth of the cotton bollworm and development of its parasitoid Campoletis chlorideae. Insect. Sci. 4, 182-188. doi: 10.1111/j.1744-7917.1997.tb00 088.x

Wilson, F. D., and Lee, J. A. (1971). Genetic relationship between tobacco budworm feeding response and gland number in cotton seedlings. Crop Sci. 11, 419-421. doi: $10.2135 /$ cropsci1971.0011183x001100030032x

Wilson, F. D., and Smith, J. N. (1977). Variable expressivity and gene action of gland-determining alleles in Gossypium hirsutum L. Crop Sci. 17, 539-542. doi: 10.2135/cropsci1977.0011183x001700040014x

Wilson, R. L., Wilson, F. D., and Abel, G. H. Jr. (1977). Mutants of Gossypium barbadense: effect on pink bollworm and cotton leafperforator in Arizona. J. Econ. Entomol. 70, 672-674. doi: 10.1093/jee/70.5.672

Wilson, R. L., Wilson, F. D., and George, B. W. (1979). Mutants of Gossypium hirsutum: effect on pink bollworm in Arizona. J. Econ. Entomol. 72, 216-219. doi: 10.1093/jee/72.2.216

Yuan, Y. L., Chen, Y. H., Tang, C. M., Jing, S. R., Liu, S. L., Pan, J. J., et al. (2000). Effects of the dominant glandless gene $\mathrm{Gl}_{2}{ }^{e}$ on agronomic and fibre characters of upland cotton. Plant Breed 119, 59-64. doi: 10.1046/j.14390523.2000.00446.x

Zhang, J. F. (2011). Twenty-five years of introgression breeding through interspecific hybridization between Gossypium hirsutum and G. barbadense. Proc. Beltwide Cotton Conf. 2011, 711-716.

Zhang, J. F., Abdelraheem, A., and Wedegaertner, T. (2021). Tolerance of Pima and Upland cotton to trifloxysulfuron (Envoke) herbicide under field conditions. J. Cotton Sci. 4:26.

Zhang, J. F., Flynn, R., Hughs, S. E., Bajaj, S., Waddell, C., and Jones, D. C. (2011). Registration of 'Acala 1517-08'Cotton. J. Plant Reg. 5, 156-163. doi: 10.3198/jpr2010.04.0237crc

Zhang, J. F., Flynn, R., Idowu, O. J., Wedegaertner, T., and Hughs, S. E. (2016a). Transgressive segregation in an Acala glanded $\times$ Acala glandless hybrid population for the development of glandless cotton germplasm. J. Cotton Sci. 20, 145-153.

Zhang, J. F., Idowu, J., Flynn, R., Hughs, S. E., Jones, D. J., and Wedegaertner, T. (2016b). Registration of glandless 'NuMex COT 15 GLS' cotton. J. Plant Reg. 10, 223-227. doi: 10.3198/jpr2015.10.0067 crc

Zhang, J. F., Idowu, J., Flynn, R., and Wedegaertner, T. (2018). Progress in breeding for glandless cotton in New Mexico. Proc. Beltwide Cotton Conf. 2018, 566-572.

Zhang, J. F., Bourland, F., Wheeler, T. A., and Wallace, T. (2020a). Bacterial blight resistance in cotton: genetic basis and molecular mapping. Euphytica 216:111.

Zhang, J. F., Idowu, O. J., and Wedegaertner, T. (2020b). Registration of glandless 'NuMex COT 17 GLS' Upland cotton cultivar with Fusarium wilt race 4 resistance. J. Plant Reg. 14, 1-9. doi: 10.1002/plr2.20020

Zhang, J. F., Lu, Y., Adragna, H., and Hughs, E. (2005). Genetic improvement of New Mexico Acala cotton germplasm and their genetic diversity. Crop Sci. 45, 2363-2373. doi: 10.2135/cropsci2005.0140

Zhang, J. F., Sanogo, S., Percy, R. G., Wedegaertner, T., and Jones, D. (2017). Evaluation of cotton for resistance to Southwestern cotton rust (Puccinia cacabata). Proc. Beltwide Cotton Conf. 117, 568-474.
Zhang, J. F., Idowu, O. J., Flynn, R., Wedegaertner, T., and Hughs, S. E. (2014a). Genetic variation and selection within glandless cotton germplasm. Euphytica 198, 59-67. doi: 10.1007/s10681-014-1083-7

Zhang, J. F., Idowu, O. J., Wedegaertner, T. M., and Hughs, S. E. (2014b). Genetic variation and comparative analysis of thrips resistance in glandless and glanded cotton under field conditions. Euphytica 199, 373-383.

Zhang, J. F., Wedegaertner, T., and Hughs, S. E. (2014c). Development of new glandless cotton germplasm. Proc. Beltwide Cotton Conf. 2014, 608-620.

Zhang, J. F., Wedegaertner, T., and Hughs, S. E. (2014d). Field evaluation of thrips resistance in glandless and glanded cotton. Proc. Beltwide Cotton Conf. 2014, 621-631.

Zhang, J. F., Percy, R. G., and McCarty, J. C. Jr. (2014e). Introgression genetics and breeding between Upland and Pima cotton- a review. Euphytica 198, 1-12. doi: 10.1007/s10681-014-1094-4

Zhang, J. F., Wedegaertner, T., Idowu, O. J., Sanogo, S., Flynn, R., Hughs, S. E., et al. (2019c). Registration of a glandless 'Acala 1517-18 GLS' cotton. J. Plant Reg. 13, 12-18. doi: 10.3198/jpr2017.05.0031crc

Zhang, J. F., Abdelraheem, A., and Wedegaertner, T. (2019b). Tolerance of commercial Upland (Gossypium hirsutum) and Pima (G. barbadense) cotton cultivars, advanced breeding lines and glandless cotton to halosulfuron (Sandea) herbicide under field conditions. Euphytica 215:3.

Zhang, J. F., Abdelraheem, A., and Flynn, R. (2019a). Genetic gains of Acala 1517 cotton since 1926. Crop Sci. 59, 1052-1061. doi: 10.2135/cropsci2018.11.0686

Zhang, X., Jin, L., and Zhang, T. (2001). A new upland cotton cultivar with glanded plant and low gossypol content seed. Sci. Agr. Sinica 34, 564-567.

Zhu, S. J., Jiang, Y., Reddy, N., and Ji, D. (2004). Breeding, introgression and inheritance of delayed gland morphogenesis trait from Gosspium bickii into upland cotton germplasm. Chin. Sci. Bull. 9, 2470-2476. doi: 10.1360/982004255

Zhu, S. J., Reddy, N., and Jiang, Y. R. (2005). Introgression of a gene for delayed pigment gland morphogenesis from Gossypium bickii into upland cotton. Plant Breed. 124, 590-594. doi: 10.1111/j.1439-0523.2005.01151.x

Zhu, Y., Lujan, P., Dura, S., Sanogo, S., and Zhang, J. F. (2017). Screening cotton for resistance to Alternaria leaf spot caused by Alternaria alternata in New Mexico. Proc. Beltwide Cotton Conf. 2017:458.

Zhu, Y., Lujan, P., Dura, S., Steiner, R., Wedegaertner, T. C., Zhang, J. F., et al. (2018). Evaluation of commercial Upland (Gossypium hirsutum) and Pima ( $G$. barbadense) cotton cultivars, advanced breeding lines and glandless cotton for resistance to Alternaria leaf spot (Alternaria alternata) under field conditions. Euphytica 214:147.

Zummo, G. R., Benedict, J. H., and Segers, J. C. (1983). No-choice study of plant-insect interactions for Heliothis zea (Boddie) (Lepidoptera: Noctuidae) on selected cottons. Environ. Entomol. 12, 1833-1836. doi: 10.1093/ee/12.6.1833

Zur, M., Meisner, J., Kabonci, E., and Ascher, K. R. S. (1978). Gossypol content of cotton leaves during the growing season, and growth suppression of Spodoptera littoralis (Boisduval) larvae on some high-gossypol (HG) cotton strains. J. Appl. Entomol. 87, 435-437. doi: 10.1111/j.1439-0418.1978.tb02469.x

Zur, M., Meisner, J., Kabonci, E., and Ascher, K. R. S. (1980). Field evaluation of the response of Spodoptera littoralis and Earias insulana to cotton strains differing in gossypol content. Phytoparasitica 8, 189-194. doi: 10.1007/bf03158315

Conflict of Interest: The authors declare that the research was conducted in the absence of any commercial or financial relationships that could be construed as a potential conflict of interest.

The handling editor declared a past co-authorship with one of the authors JZ.

Publisher's Note: All claims expressed in this article are solely those of the authors and do not necessarily represent those of their affiliated organizations, or those of the publisher, the editors and the reviewers. Any product that may be evaluated in this article, or claim that may be made by its manufacturer, is not guaranteed or endorsed by the publisher.

Copyright (C) 2021 Zhang and Wedegaertner. This is an open-access article distributed under the terms of the Creative Commons Attribution License (CC BY). The use, distribution or reproduction in other forums is permitted, provided the original author(s) and the copyright owner(s) are credited and that the original publication in this journal is cited, in accordance with accepted academic practice. No use, distribution or reproduction is permitted which does not comply with these terms. 